\title{
PENGARUH STRATEGI INOVASI TERHADAP KINERJA OPERASIONAL PERUSAHAAN MANUFAKTUR
}

\author{
R i t a \\ Jurusan Manajemen, Fakultas Ekonomi dan Bisnis, Universitas Bina Nusantara, \\ Jln. K.H. Syahdan No. 9, Palmerah, Jakarta Barat 11480 \\ rita@binus.ac.id
}

\begin{abstract}
This research examines the effect of innovation strategy towards operational performance of manufacturing companies in Sulawesi. Dimensions of innovation strategy are leadership orientation, process innovation, product innovation, and implementation of innovation. Operational performance is measured by using productivity, volume of production defect, warranty claims cost, quality cost, and full on time delivery to consumers. Data collecting was conducted through questionnares, which consisted of 63 respondents. Data is processed with multiple regressions. Results of this research indicate direct significant effect among the dimensions of innovation strategy to the operational performance of manufacturing companies. But not all of them have an effect on operational performance of the manufacturing company. Process innovation, product innovation, and implementation of innovation give significant effect to the operational performance. Leadership orientation does not give significant effect to the operational performance of the manufacturing companies in Sulawesi.
\end{abstract}

Keywords: innovation strategy, operational performance, manufacturing

\begin{abstract}
ABSTRAK
Penelitian ini menguji pengaruh strategi inovasi terhadap kinerja operasional perusahaan manufaktur di Sulawesi. Dimensi strategi inovasi adalah orientasi kepemimpinan, inovasi proses, inovasi produk, dan pelaksanaan inovasi. Kinerja operasional diukur dengan menggunakan produktivitas, cacat volume produksi, biaya garansi claims, biaya kualitas, dan pengiriman tepat waktu secara penuh kepada konsumen. Metode pengumpulan data dilakukan melalui questionnares, yang terdiri dari 63 responden. Pengolahan data dilakukan dengan regresi berganda. Hasil penelitian ini menunjukkan pengaruh langsung yang signifikan antara dimensi strategi inovasi terhadap kinerja operasional perusahaan manufaktur. Tapi tidak semua dari mereka mempengaruhi kinerja operasional perusahaan manufaktur. Proses inovasi, inovasi produk, dan implementasi inovasi memberikan pengaruh signifikan terhadap kinerja operasional. Sementara orientasi kepemimpinan tidak memberikan pengaruh yang signifikan terhadap kinerja operasional perusahaan manufaktur di Sulawesi.
\end{abstract}

Kata kunci: strategi inovasi, kinerja operasional, manufaktur 


\section{PENDAHULUAN}

Ketika sebuah organisasi mulai memberikan perhatian pada lingkungan kompetisi global, maka inovasi akan menjadi salah satu faktor kunci kesuksesan. Cottam (2001) menyatakan bahwa inovasi merupakan salah satu alternatif bagi organisasi untuk bertahan hidup dalam lingkungan yang dinamis dan bergejolak. Johne (1999) sependapat bahwa bisnis yang bergerak dalam lingkungan persaingan yang sangat ketat dituntut untuk inovatif. Jika bisnis tidak inovatif, maka bisnis tersebut akan menghadapi risiko untuk sulit bertahan hidup dalam lingkungan persaingan yang ketat. Inovasi diakui sebagai faktor yang sangat penting dalam persaingan industri dan merupakan senjata yang tangguh untuk menghadapi persaingan (Avionitis dan Tzokas, 1994), disamping itu juga inovasi merupakan faktor kunci bagi keberhasilan perusahaan (Frambach dan Schilleweart, 2002). Hal ini mencerminkan betapa pentingnya inovasi bagi organisasi dalam lingkungan bisnis dewasa ini.

Inovasi dan pengembangan produk pada perusahaan manufaktur khususnya, merupakan hal penting yang harus diperhatikan dalam peningkatan produktivitas dan penciptaan competitive dalam persaingan global. Inovasi manufaktur mencakup penciptaan, pemilihan, dan pengembangan/ peningkatan produk, proses, dan teknologi (Zahra dan Das, 1993). Inovasi tersebut dapat meningkatkan posisi global perusahaan dan membantu untuk mencapai status sebagai produsen yang berkualitas kelas dunia. Dalam melakukan inovasi, perusahaan perlu mengembangkan suatu strategi inovasi formal dan menyeluruh. Strategi ini mengungkapkan tujuan perusahaan dalam melakukan inovasi, yaitu dengan menjelaskan apa yang akan diinovasi dan bagaimana melakukannya.

Berdasarkan teori-teori dan hasil penelitian yang belum konsisten tentang strategi inovasi dan pengaruhnya pada kinerja perusahaan, maka penulis mencoba mengangkat permasalahan yang akan menjadi fokus dalam penelitian ini, yaitu (1) Apakah orientasi kepemimpinan berpengaruh positif terhadap kinerja operasional perusahaan manufaktur, (2) Apakah inovasi proses berpengaruh positif terhadap kinerja operasional perusahaan manufaktur, (3) Apakah inovasi produk berpengaruh positif terhadap kinerja operasional perusahaan manufaktur, dan (4) Apakah implementasi Inovasi berpengaruh positif terhadap kinerja operasional perusahaan manufaktur. Berdasarkan pada permasalahan yang telah diungkapkan sebelumnya, maka penelitian ini bertujuan untuk menganalisis pengaruh (1) Orientasi kepemimpinan terhadap kinerja operasional perusahaan manufaktur, (2) Inovasi proses terhadap kinerja operasional perusahaan manufaktur, (3) Inovasi produk terhadap kinerja operasional perusahaan manufaktur, dan (4) Implementasi inovasi terhadap kinerja operasional perusahaan manufaktur.

Strategi merupakan pola atau rencana yang memadukan tujuan pokok, kebijakan dan tindakan-tindakan organisasi. Pada perspektif lain, strategi didefinisikan sebagai rencana yang disatukan, menyeluruh dan terpadu serta mengkaitkan keunggulan strategi organisasi dengan tantangan lingkungan. Porter (1990) menyatakan bahwa strategi harus dirumuskan secara eksplisit, agar kebijakan-kebijakan fungsional dapat mengkordinasi dan mengarahkan devisi bidang fungsional pada pencapaian tujuan dan misi perusahaan. Pendapat lain yang dikemukakan oleh Kenneth Andrews dalam Minzberg dan Quinn (1991), menyatakan bahwa strategi adalah suatu pola pencapaian tujuan, sasaran dan kebijakan serta rencana untuk mencapai tujuan dengan mendifinisikan bisnis yang ada dan jenis perusahaannya.

Dimensi-dimensi strategi inovasi, yaitu orientasi kepemimpinan, inovasi proses, inovasi produk, dan implementasi inovasi. Pertama, orientasi kepemimpinan. Dimensi ini menunjukkan apakah suatu peusahaan mengikuti a first-to market (pertama masuk pasar), second-to-market (kedua masuk pasar), atau late-entrant (sebagai pengikut), imitator posture (bersikap peniru) dalam kegiatan inovasi (Porter, 1990). Dalam suatu konteks manufaktur, sebuah perusahaan yang mengambil sikap pertama masuk pasar, biasanya ciri khas dari inovasi-inovasi produk dan proses, menggunakan yang baru dan unik dari produknya untuk memperoleh suatu competitive edvantage. 
Orientasi perusahaan terhadap kepemimpinan inovasi merupakan hal penting untuk dikembangkan guna memperbaiki kinerja perusahaan (Melum, 2002). Selanjutnya, Zahra dan Das (1993) juga menyatakan bahwa orientasi kepemimpinan secara langsung akan menentukan kinerja perusahaan. Berdasarkan penelitian sebelumnya, maka hipotesis dirumuskan sebagai berikut:

H1: Orientasi kepemimpinan berpengaruh positif terhadap kinerja operasional perusahaan manufaktur.

Kedua, inovasi proses. Inovasi proses didefinisikan sebagai suatu elemen baru yang diperkenalkan dalam operasi produk dan jasa dalam perusahaan, seperti materi bahan baku, spesifikasi tugas, mekanisme, maupun peralatan yang digunakan untuk memproduksi produk atau jasa (Damanpour, 1991). Inovasi proses menggambarkan perubahan dalam cara organisasi memproduksi produk atau jasa akhir dari suatu perusahaan (Cooper, 1998; Utterback, 1994). Inovasi proses mencakup tahapan dari produk baru, jasa atau pengembangan proses, dari konsepsi gagasan sampai dengan penerimaan di pasar (Perez Bustamante, 1999). Menurut Cumming (1998), inovasi proses meliputi fungsi kualitas dan pengembangan proses bisnis (business process reengineering). Di samping itu, inovasi proses merupakan saran untuk meningkatkan kualitas dan juga penghematan biaya (Johne, 1999). Hal ini mencerminkan bahwa adopsi proses inovasi diakui dapat meningkatkan efisiensi dan produktifitas proses produksi.

Ketiga, inovasi produk. Damanpour (1991) mendefinisikan inovasi produk sebagai produk atau jasa baru yang diperkenalkan ke pasar untuk memenuhi kebutuhan pasar. Lebih lanjut, inovasi produk didefinisikan oleh Lukas dan Ferrel (2000) sebagai proses memperkenalkan teknologi baru untuk digunakan. Hasil proses ini adalah pengenalan produk atau jasa baru yang dapat dijadikan sebagai alat untuk memperoleh keuntungan bagi perusahaan (Johne 1999). Jenis inovasi ini mencerminkan perubahan dalam produk dan jasa yang ditawarkan perusahaan di pasar (Cooper, 1998; Utterback, 1994). Dalam hal ini, produk atau jasa harus diperbaharui secara lengkap agar dapat memperkuat posisinya di pasar (Johne, 1999). Mavondo dan farrel (2003) menjelaskan ada 3 aktivitas organisasi yang mencirikan tingkat inovasi yang tinggi, yaitu kemampuan untuk mengamati peluang pasar, membangun kapabilitas pemasaran dalam rangka menanggapi peluang pasar, dan kemampuan untuk menangkap peluang pasar dengan cepat.

(Thurow dalam Zahra dan Das, 1993) mengatakan bahwa fungsi pengembangan produk, dan pengembangan proses paling baik adalah jika keduanya digabung. Selanjutnya, sebagai pasar dari industri yang matang, usaha-usaha inovasi cenderung bergeser dari menciptakan produk kemengurangi biaya inovasi-inovasi proses (Khan dan Manopicketwattana, 1989). Perusahaan bisa merubah berbagai macam kombinasi dari inovasi produk dan proses yang mereka inginkan (Porter, 1985). Sedangkan Ettlie dan Reza (1992) menyatakan bahwa inovasi proses dan inovasi produk dapat mempengaruhi kinerja perusahaan, baik secara parsial maupun bersama-sama (simultan). Hal ini menjadi dasar munculnya hipotesis berikut:

H2: Inovasi proses berpengaruh positif terhadap kinerja operasional perusahaan manufaktur.

H3: Inovasi produk berpengaruh positif terhadap kinerja operasional perusahaan manufaktur.

Keempat, implementasi inovasi. Implementasi inovasi dalam suatu organisasi dapat diartikan sebagai proses memperoleh karyawan yang tepat dan bertanggung jawab dalam menggunakan inovasi (Klein dan Sorra, 1996). Implementasi inovasi merupakan keputusan yang dibuat oleh manajer senior suatu organisasi yang akan menggunakan inovasi dalam pekerjaannya. Tujuan fundamental dari implementasi inovasi adalah merubah perilaku individu dalam organisasi (anggota organisasi). Menurut Read (2000), implementasi inovasi adalah suatu proses manajemen yang mendukung dan berusaha menuju perubahan budaya yang harus berasal dari puncak organisasi. Skenario ideal untuk keberhasilan implementasi inovasi adalah karyawan menjadi terampil, konsisten dan bertanggung jawab dalam penggunaan inovasi. 
Keberhasilan inovasi tergantung pada penggunaan inovasi oleh seluruh anggota organisasi bukan pada individu saja (Tornatsky dan Fleicscher, 1990 dalam Klein dan Sorra, 1996). Selanjutnya Klein dan Sorra (1996) mengatakan bahwa implementasi inovasi jika efektif akan dapat meningkatkan kinerja organisasi. Uraian di atas menunjukkan bahwa dalam rangka melakukan aktivitas inovasinya, suatu organisasi sebaiknya didukung dengan inovasi proses dalam proses produksinya serta bagaimana karyawan mampu mengimplementasikan inovasi tersebut dalam meningkatkan kinerja organisasi. Berdasarkan uraian di atas, maka dapat dirumuskan hipotesis sebagai berikut:

H4: Implementasi inovasi berpengaruh positif terhadap kinerja operasional perusahaan manufaktur.

Kinerja operasional. Ketepatan ukuran kinerja yang digunakan dalam suatu penelitian tergantung pada situasi dan kondisi dalam suatu studi. Literatur menjelaskan bahwa dalam hampir semua situasi, ukuran kinerja organisasi adalah dengan menggunakan profitabilitas dan pertumbuhan keuangan (Nash, 1984 dikutip dalam Ettlie, 2003). Profitabilitas keuangan diukur melalui profit margin return on asset, return on equity, return on sales yang merupakan ukuran umum yang digunakan untuk mengukur profitabilitas financial (Galbraight dan Scendel, 1983 dikutip dalam Ettlie, 2003). Pengukuran kinerja operasional diukur melalui beberapa dimensi pengukuran, yaitu biaya produk perunit, kualitas produk, kualitas proses, kemampuan menangani perubahan jumlah permintaan, kemampuan memenuhi perubahan selera pelanggan, pengiriman tepat waktu, dan kemampuan pengiriman sebelum waktu yang ditentukan (Leong et al, 1990:120).

Penelitian ini lebih menekankan pada kinerja operasional perusahaan. Kinerja operasional peneliti mengacu pada pendapat Schroeder (1993) yang mengatakan bahwa pengukuran kinerja yang tepat sebaiknya diperoleh dari hasil penerapan operasi dan bisnis, yang ditunjukkan dengan kualitas, biaya, delivery, fleksiblitas, dan inovasi. Kinerja operasional dalam penelitian ini menggunakan indikator kinerja yang dikemukakan oleh Terziovski dan Samson (1999), yang dapat diukur melalui tingkat produktivitas, tingkat kesalahan produk, biaya jaminan atau garansi, biaya kualitas, dan ketepatan waktu produk sampai ketangan konsumen.

Penelitian-penelitian sebelumnya. Penelitian-penelitian sebelumnya yang memfokuskan baik pada strategi inovasi maupun kinerja perusahaan yang digunakan sebagai dasar dalam pengembangan hipotesis penelitian ini, yaitu (1) Kemp, et al (2003), menganalisis hubungan antara inovasi dengan kinerja perusahaan pada perusahaan kecil, menengah, dan besar. Menemukan adanya perbedaan proses inovasi antara perusahaan kecil, menengah, dan besar serta ukuran perusahaan (size) berpengaruh positif terhadap kinerja perusahaan; (2) Read (2000), menguji inovasi sebagai faktor kesuksesan organisasi, hasil penelitian tersebut menunjukkan bahwa implementasi inovasi berpengaruh positif terhadap kinerja perusahaan. Dalam hal ini kegagalan organisasi untuk mencapai keunggulan disebabkan oleh kegagalan dalam mrngimplementasikan inovasi; (3) Sharma dan Fisher (1997), menguji pengaruh strategi-strategi fungsional (strategi produktivitas, inovasi, teknologi, pemasaran, organisasional, dan keuangan) terhadap daya saing perusahaan yang ditunjukkan dengan kinerja perusahaan. Secara parsial maupun bersama-sama masing-masing strategi fungsional memiliki pengaruh yang signifikan terhadap kinerja perusahaan, dan strategi produktivitas memiliki pengaruh terbesar diantara strategi fungsional lainnya; (4) Zahra dan Das (1993), meneliti tentang hubungan antara strategi inovasi dengan kinerja keuangan perusahaan manufaktur. Hasil penelitian tersebut menunjukkan bahwa strategi inovasi berpengaruh positif terhadap kinerja keuangan perusahaan, baik secara langsung maupun tidak langsung.

Model penelitian. Mengacu pada berbagai tinjauan konseptual, yaitu penelitian yang dilakukan oleh Zahra dan Das (1993), Read (2000), Terziovski \& Samson (1999), dan Kemp, et al (2003), tentang inovasi dan kinerja perusahaan, maka peneliti mencoba memodifikasi penelitian ini dengan memasukkan implementasi inovasi sebagai dimensi dari strategi inovasi, dan kinerja non keuangan sebagai sebagai pengukuran kinerja perusahaan serta ukuran perusahaan (size) sebagai variabel kontrol, dengan mengadaptasi model penelitian (model simultan) yang dikemukakan oleh 
Zahra dan Das (1993). Model penelitian yang digunakan untuk menguji pengaruh orientasi kepemimpinan, inovasi proses, inovasi produk terhadap kinerja operasional perusahaan, dapat dilihat pada Gambar 1.

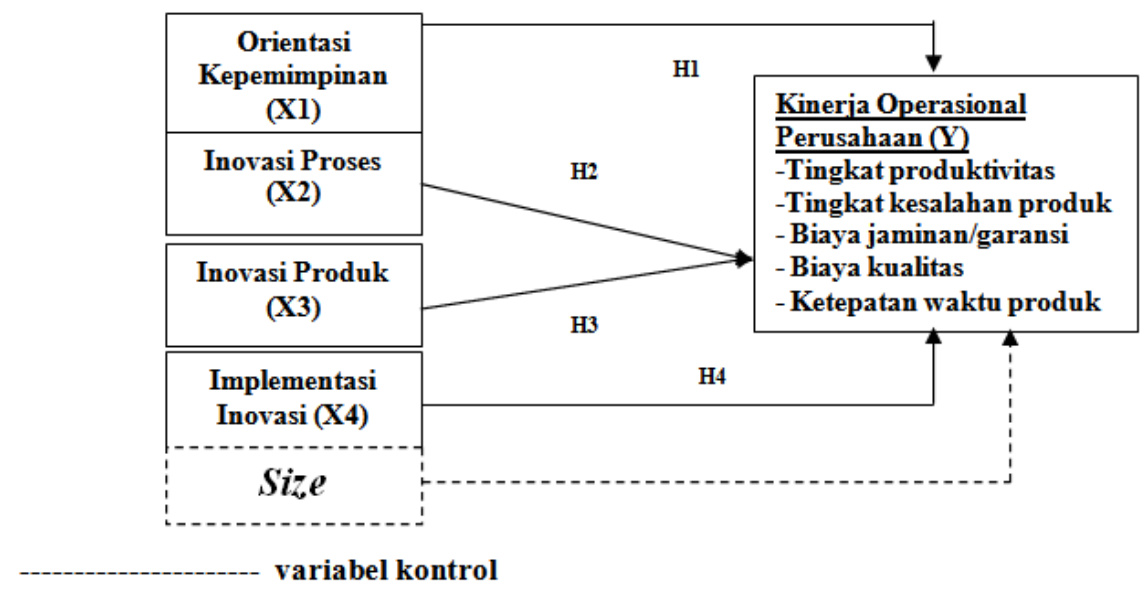

Gambar 1 Model Penelitian

Sumber: Diadaptasi dari Zahra, S.A \& Das, S.R, (1993),

Terziovski \& Samson (1999), Read (2000), dan Kemp, et al (2003)

\section{METODE PENELITIAN}

\section{Populasi dan Sampel}

Populasi dalam penelitian ini adalah semua perusahaan manufaktur yang beroperasi di Sulawesi dan terdaftar dalam Direktori Industri Pengolahan yang diterbitkan oleh Biro Pusat Statistik (BPS) pada tahun 2003. Industri pengolahan (manufacturing) adalah suatu kegiatan ekonomi yang melakukan kegiatan mengubah suatu barang dasar secara mekanis, kimia, atau dengan tangan sehingga menjadi barang jadi atau setengah jadi dan atau barang yang kurang nilainya menjadi barang yang lebih tinggi nilainya dan sifatnya lebih dekat kepada pemakai akhir. Sedangkan perusahaan manufaktur merupakan suatu unit kesatuan usaha yang melakukan kegiatan ekonomi yang bertujuan untuk menghasilkan barang, terletak pada suatu bangunan atau lokasi tertentu, dan mempunyai catatan administrasi tersendiri mengenai produksi struktur biaya serta ada seorang atau lebih yang bertanggung jawab atas usaha tersebut (BPS, 2003).

Penggolongan atau klasifikasi industri yang digunakan dalam penelitian ini adalah klasifikasi berdasarkan data statistik industri besar, dan sedang yang diterbitkan oleh BPS (2003). Klasifikasi berdasarkan International Standar Industrial Classification (ISIC) yang telah disesuaikan dengan kondisi di Indonesia yang lebih dikenal dengan Klasifikasi Lapangan Usaha Industri (KLUI) (BPS, 2003). Penggolongan skala perusahaan dibagi dalam 4 golongan, yaitu (1) Besar, dengan jumlah tenaga kerja 100 orang atau lebih; (2) Sedang, dengan jumlah tenaga kerja 20-99 orang; (3) Kecil, dengan jumlah tenaga kerja 5-19 orang; dan (4) Rumah tangga, dengan jumlah tenaga kerja 1-4 orang. Jumlah populasi dalam penelitian ini tidak diketahui.

Besarnya sampel yang akan digunakan dalam penelitian ini adalah minimal 60 sampel, karena jumlah variabel yang digunakan dalam penelitian ini sebanyak 6 variabel. Penelitian ini menggunakan 
multisource dengan perincian 3 responden dalam setiap sampel, yaitu satu orang manajer umum, satu orang manajer operasional, dan satu orang manajer penelitian dan pengembangan (R\&D), dan masingmasing responden mendapat kesempatan untuk menjawab semua pertanyaan yang sama. Data pada level perusahaan diperoleh dari hasil rata-rata jawaban individu responden.

\section{Metode Pengumpulan Data}

Studi pada penelitian ini menggunakan data primer. Data primer diperoleh melalui penyebaran kuesioner (mailed questionnaires) pada perusahaan-perusahaan manufaktur yang berskala menengah dan besar, dengan manajer umum, manajer operasional, dan manajer R\&D sebagai target subjek. Metode ini dipilih dengan pertimbangan untuk menjangkau area penelitian yang luas dengan biaya yang relatif murah, lebih mampu merahasiakan identitas responden dan memberikan kesempatan kepada responden untuk berpikir sebelum memberikan jawaban pertanyaan. Metode tersebut di atas memiliki kelemahan yaitu rendahnya tingkat respon atau partisipasi responden, tidak ada intervensi pewawancara, format kuesioner harus dibuat dalam bentuk yang menarik dengan pertanyaan yang singkat dan jelas dan hanya membutuhkan waktu \pm 15 menit untuk menjawabnya serta diperlukan daftar pengiriman surat yang akurat. Pendistribusian kuesioner juga dilakukan dengan cara mendatangi secara langsung beberapa perusahaan manufaktur yang menjadi objek penelitian.

\section{Definisi Operasional dan Pengukuran Variabel}

Studi ini mengadaptasi beberapa pengukuran (construct) strategi inovasi dan kinerja operasional perusahaan. Pengukuran strategi inovasi mengacu dari penelitian Zahra dan Das (1993), Klein dan Sorra (1996), dan Read (2000). Sedangkan ukuran perusahaan (size) sebagai variabel kontrol mengacu dari penelitian Kemp, et al (2003). Selanjutnya pengukuran kinerja operasional perusahaan mengacu dari penelitian Schroeder (1993), dan menggunakan indikator kinerja yang dikemukakan oleh Terziovski dan Samson (1999). Definisi operasional dan pengukuran masingmasing variabel akan dijelaskan sebagai berikut.

Pertama, orientasi kepemimpinan. Dimensi ini mengindikasikan orientasi kepemimpinan perusahaan dalam melakukan proses inovasi, apakah sebagai yang pertama kali memasuki pasar (firstto-the-market), perusahaan sebagai pemain kedua yang memasuki pasar (second-to-the-market), atau pemain yang terakhir (late-entrant). Konsisten dengan definisi kepemimpinan inovasi menurut Foster dan Kimura dalam Zahra dan Das (1993), yang menyatakan bahwa pemimpin/pelopor inovasi adalah yang pertama mengembangkan dan memperkenalkan produk-produk baru pada pasar. Orientasi kepemimpinan merupakan variabel penentu bagi aktivitas inovasi selanjutnya. Dimensi ini diukur melalui 6 item pernyataan dengan 5 skala likert dari 1 (sangat tidak ditekankan) hingga 5 (sangat ditekankan).

Kedua, inovasi proses. inovasi proses merupakan bentuk inovasi yang menekankan pada metode-metode baru dalam pengoperasian, dengan cara membuat teknologi baru atau mengembangkan teknologi yang telah ada (Leonard Barton, 1991). Dimensi ini diukur melalui 4 item pernyataan, pernyataan yang diajukan berkisar pada pengembangan metode dan prosedur untuk produk baru, pengenalan metode baru untuk produksi yang lebih cepat dibanding pesaing, dengan 5 skala likert dari 1 (sangat tidak ditekankan) hingga 5 (sangat ditakankan).

Ketiga, inovasi produk. Inovasi produk merupakan hasil penciptaan dan pengenalan produk secara radikal atau modifikasi produk yang telah ada sehingga tipe inovasi ini lebih menekankan pada pengembangan produknya (Krubasik, 1988). Dimensi inovasi produk yang terbagi dalam 5 item pernyataan, pernyataan yang diajukan ditekankan pada tingkat inovasi produk, komitmen untuk memperkenalkan produk lebih banyak dibanding pesaing dan juga penekanan pada modifikasi produk yang sudah ada, dengan 5 skala likert dari 1 (sangat rendah) hingga 5 (sangat tinggi). 
Keempat, implementasi inovasi. Dimensi ini difokuskan pada pengadopsian inovasi, konsisten dengan definisi Read (2000), bahwa pengadopsian inovasi adalah akuisisi dan atau implementasi inovasi. Dimensi ini menggunakan 3 item pernyataan berdasarkan penelitian Klein dan Sorra (1996). Pernyataan tersebut menekankan pada iklim organisasi, antusias dan kreatifitas karyawan dalam menggunakan metode atau teknologi baru. Skala pengukuran yang digunakan adalah skala kategori dari skala 1 (sangat rendah) sampai dengan skala 5 (sangat tinggi).

Kelima, ukuran perusahaan (size). Dalam penelitian ini, size dimasukkan sebagai variabel kontrol yang berguna untuk mengetahui tingkat kesalahan interpretasi hasil akibat adanya variabel lain yang berpengaruh, yang tidak disertakan dalam penelitian. Baldwin, et al (2000) menyatakan bahwa size berpengaruh secara signifikan terhadap kemampuan inovasi, lebih lanjut dalam penelitiannya menemukan bahwa perusahaan yang lebih besar, lebih inovatif dibandingkan dengan perusahaan kecil karena perusahaan besar mempunyai kemudahan didalam pembiayaan dan mempunyai penelitian dan pengembangan yang formal.

Selanjutnya, hasil penelitian Kemp, et al (2003), menunjukkan adanya perbedaan proses inovasi antar perusahaan kecil, menengah, dan besar dan inovasi memiliki hubungan dengan kinerja perusahaan, begitu pula dengan size, juga memiliki pengaruh yang positif terhadap kinerja perusahaan. Sharma (2000), juga menyatakan bahwa size adalah variabel kontrol yang penting, makin besar perusahaan dan semakin luas operasinya maka sumberdaya yang dimilikinya juga semakin besar untuk melakukan tanggung jawab sosial. Dalam penelitian ini, menggunakan jumlah tenaga kerja yang dimiliki oleh masing-masing perusahaan sebagai indikator dari size berdasarkan BPS (2003).

Keenam, kinerja operasional perusahaan. Kinerja merupakan hasil yang diinginkan dari perilaku (Gibson dan Donelly, 1995). Kinerja organisasional merupakan hasil yang diinginkan organisasi dari perilaku orang-orang didalamnya. Kinerja ini dapat diperbaiki, apabila tujuan organisasi dikombinasikan dengan umpan balik (Noori dan Radford, 1995). Ukuran kinerja perusahaan dapat dikelompokkan kedalam kinerja keuangan dan kinerja operasional. Penelitian ini menggunakan kinerja operasional yang meliputi tingkat produktivitas, tingkat kesalahan produk, biaya jaminan atau garansi, biaya kualitas dan tingkat penyampaian produk ketangan konsumen tepat waktu. Dalam penelitian ini, ukuran yang digunakan untuk kinerja operasional adalah tingkat produktivitas, tingkat kesalahan produk, biaya garansi, biaya kualitas dan ketepatan waktu produk sampai ketangan konsumen (Terziovski dan Samson, 1999).

Metode analisis. Dalam penelitian ini, pengujian hipotesis dilakukan dengan menggunakan analisis regresi berganda (multiple regression analysis). Metode analisis ini digunakan karena dalam pengujian hipotesis terdapat lebih dari satu variabel independen. Perhitungan dilakukan dengan meggunakan bantuan software SPSS 12 for windows (Ghozali, 2005).

\section{HASIL DAN PEMBAHASAN}

\section{Karakteristik Responden}

Data penelitian dikumpulkan dengan mengirimkan kuesioner sebanyak 450 eksemplar untuk 150 perusahaan manufaktur berskala menengah dan besar di Sulawesi, yaitu 345 eksemplar untuk 115 perusahaan dikirimkan melalui pos, dan 105 eksemplar untuk 35 perusahaan diberikan langsung pada perusahaan yang menjadi target responden. Dari 115 (76,67\%) perusahaan yang telah dikirimkan kuesioner, 9 kuesioner untuk 3 perusahaan kembali (perusahaan pindah alamat atau tutup). Total perusahaan yang mengembalikan kuesioner 48 perusahaan dan 6 di antaranya tidak diisi secara lengkap sehingga tidak dapat digunakan dalam analisis data. 
Tabel 1 Sampel dan Tingkat Pengembalian

\begin{tabular}{lc}
\hline \multicolumn{1}{c}{ Keterangan } & Jumlah Data \\
\hline Total perusahaan yang dikirimkan kuesioner & 150 \\
Kuesioner tidak diisi secara lengkap & 6 \\
Total perusahaan yang mengembalikan kuesioner & 69 \\
Tingkat pengembalian kuesioner 69/150 x 100\% & $46 \%$ \\
Tingkat pengembalian kuesioner yang diolah 63/150 x 100\% & $42 \%$ \\
Jumlah perusahaan besar yang berpartisipasi & 18 \\
Jumlah perusahaan menengah yang berpartisipasi & 45 \\
\hline
\end{tabular}

Sumber: data diolah

\section{Pengujian Hipotesis dan Pembahasan}

Pengujian hipotesis dalam penelitian ini menggunakan regresi berganda (multiple regression) dengan memasukkan size sebagai variabel kontrol. Alat analisis regresi berganda digunakan untuk menguji signifikansi pengaruh variabel-variabel independen (orientasi kepemimpinan, inovasi proses, inovasi produk, dan implementasi inovasi), dan size (variabel kontrol) secara bersama-sama terhadap variabel dependen (kinerja operasional).

Tabel 2 Hasil Pengujian Multiple Regression dengan variabel Kontrol (Size)

\begin{tabular}{lcccc}
\multicolumn{1}{c}{$\begin{array}{c}\text { Variabel } \\
\text { Independen }\end{array}$} & Koefisien & $\begin{array}{c}\text { Standar } \\
\text { Error }\end{array}$ & t & Sig t \\
\hline Orientasi Kepemimpinan & -0.003 & 0.114 & -0.030 & 0.976 \\
Inovasi Proses & 0.563 & 0.151 & 5.479 & 0.000 \\
Inovasi Produk & 0.420 & 0.157 & 4.147 & 0.000 \\
Implementasi Inovasi & 0.235 & 0.128 & 2.577 & 0.013 \\
Size & 0.072 & 0.147 & 0.664 & 0.510 \\
\hline $\mathrm{R}^{2}$ & & & \multicolumn{2}{c}{0.560} \\
Adjusted R & & & \multicolumn{2}{c}{0.521} \\
F & & & \multicolumn{2}{c}{0.000} \\
Sig F & & & \multicolumn{2}{c}{} \\
\hline
\end{tabular}

a. Dependent Variabel: $Y$

Sumber: data diolah

Berdasarkan Tabel 2, hasil pengujian menunjukkan bahwa secara bersama-sama orientasi kepemimpinan, inovasi proses, inovasi produk, implementasi inovasi, dan size mempunyai pengaruh yang signifikan, yang berarti secara bersama-sama dapat memberikan pengaruh yang positif terhadap kinerja operasional perusahaan. Namun demikian, nilai $\mathrm{R}^{2}$ dalam model ini sangat rendah, yaitu hanya 0.560, yang berarti bahwa 56\% dari variasi kinerja operasional perusahaan bisa dijelaskan oleh variabel orientasi kepemimpinan, inovasi proses, inovasi produk, implementasi inovasi, dan size; selebihnya dijelaskan oleh variabel-variabel lain, yang tidak diikutkan dalam model. Akan tetapi, jika dilihat dari besarnya kontribusi yang diberikan oleh masing-masing variabel strategi inovasi terhadap kinerja operasional perusahaan, 3 di antaranya (inovasi proses, inovasi produk, dan implementasi inovasi) adalah signifikan pada level $\alpha \leq 0.05$. Sedangkan orientasi kepemimpinan dan size, tidak berpengaruh secara signifikan terhadap kinerja operasional perusahaan.

Pertama, pengunjian hipotesis 1 (orientasi kepemimpinan berpengaruh terhadap kinerja operasional perusahaan). Orientasi kepemimpinan dalam penelitian ini berdasarkan pada persepsi manajer terhadap sikap yang diambil perusahaan dalam melakukan inovasi, apakah bersikap sebagai pelopor, sebagai pengikut, atau sebagai peniru. Dari hasil pengujian menunjukkan bahwa orientasi 
kepemimpinan tidak berpengaruh secara signifikan terhadap kinerja operasional perusahaan. Tidak konsisten dengan hasil penelitian Zahra dan Das (1993). Tidak konsistennya hasil penelitian ini disebabkan oleh variabel orientasi kepemimpinan dalam penelitian ini bersifat market oriented. Akan lebih tepat bila variabel orientasi kepemimpinan yang digunakan adalah orientasi kepemimpinan teknologi.

Kedua, pengunjian hipotesis 2 (inovasi proses berpengaruh positif terhadap kinerja operasional perusahaan manufaktur). Hasil pengujian menunjukkan bahwa inovasi proses memiliki pengaruh positif terhadap kinerja operasional perusahaan, yang ditunjukkan dengan hasil uji signifikansi 0.000 yang berarti signifikan pada tingkat $\alpha=5 \%$ (tabel 2). Konsisten dengan hasil penelitian Zahra dan Das (1993), dan penelitian Kemp, et al (2003). Untuk inovasi proses, hasil penelitian ini menunjukkan bahwa perusahaan tidak menemui masalah dengan inovasi prosesnya, ini berarti perusahaan telah berhasil dalam mengembangkan inovasi prosesnya. Skinner (1984) mengemukakan bahwa inovasi dalam peralatan operasi dan teknologi proses dapat digunakan secara strategis sebagai suatu alat kompetitif yang sangat ampuh. Inovasi tersebut juga membantu perusahaan untuk mencapai skala atau skop penghematan yang dapat digunakan untuk harga dan biaya yang lebih rendah. Ketiga, pengunjian hipotesis 3 (inovasi produk berpengaruh positif terhadap kinerja operasional perusahaan). Hasil pengujian menunjukkan bahwa inovasi produk memiliki pengaruh yang positif dan signifikan terhadap kinerja operasional perusahaan. Uji signifikansi menujukkan hasil 0.000 yang berarti signifikan pada tingkat $\alpha=5 \%$ (Tabel 2). Hasil penelitian ini konsisten denagn hasil penelitian Zahra dan Das (1993). Hal ini menandakan bahwa perusahaan cukup berhasil dalam pengembangan produk (inovasi produk) dan sesuai dengan apa yang diharapkan yaitu menghasilkan produk-produ baru yang menguntungkan, dan disukai konsumen. Morse (1998) mengatakan bahwa bentuk yang manapun dalam pengembangan produk baru (inovasi produk) harus memenuhi beberapa kriteria, yaitu memenuhi tujuan, yakni produk-produk baru yang menguntungkan, dan menghindari investasi yang berlebihan dalam proyek-proyek yang gagal dan produk-produk yang tidak terurus.

Keempat, pengunjian hipotesis 4 (implementasi inovasi berpengaruh terhadap kinerja operasional perusahaan). Hasil pengujian menunjukkan bahwa implementasi inovasi berpengaruh positif dan signifikan terhadap kinerja operasional perusahaan. Uji signifikansi menunjukkan hasil 0.013 yang berarti signifikan pada tingkat $\alpha=5 \%$ (Tabel 2). Hasil penelitian ini konsisten dengahn hasil penelitian Read (2000). Pengaruh ini memperlihatkan bahwa perusahaan manufaktur mendukung implementasi inovasi, dalam hal ini penggunaan atau penerapan metode/teknologi baru. Dengan demikian, karyawan mendapat iklim yang cukup mendukung dalam mengimplementasikan metodemetode baru atau inovasi, mereka antusias terhadap metode-metode tersebut dan mereka juga cukup kreatif menggunakannya. Bagi perusahaan yang memberi iklim yang sangat mendukung implementasi metode-metode atau teknologi baru bagi karyawan mereka, maka organisasi ini sadar akan kemampuan karyawan merupakan investasi yang dapat memberikan kontribusi yang luar biasa bagi perusahaan yang bersangkutan (Read, 2000). Iklim yang sangat mendukung karyawan dalam implementasi inovasi cenderung membuat karyawan lebih antusias menerapkannya dan mampu menghasilkan nilai positif diluar dugaan bagi organisasi. Sebaliknya, sebagian juga perusahaan merasa cukup nyaman dengan kondisi yang ada. Iklim yang sudah terbentuk umumnya sulit untuk diubah sehingga antusiasme karyawan dalam menerapkan metode-metode baru juga tidak terlalu tinggi sementara kreativitas cenderung jarang muncul.

Kelima, pengunjian variabel kontrol (size). Variabel kontrol dalam penelitian ini adalah ukuran perusahan (size) dengan menggunakan jumlah karyawan sebagai proksi dari size sesuai Standar Biro Pusat Statistik (BPS). Hasil pengujian menunjukkan bahwa ukuran perusahaan tidak berpengaruh secara signifikan terhadap kinerja operasional perusahaan. Berbeda dengan hasil penelitian yang dilakukan oleh Kemp, et al (2003), yang menunjukkan bahwa size berpengaruh terhadap kinerja perusahaan. Perbedaan hasil penelitian ini dengan hasil penelitian sebelumnya disebabkan penelitian ini hanya menggunakan jumlah tenaga kerja yang dimiliki oleh masing-masing 
perusahaan sebagai proksi dari size. Alasan ini didukung oleh hasil penelitian Zhou dan Stan (1998), yang menunjukkan bahwa size berpengaruh terhadap kinerja perusahaan. Proksi yang digunakan dalam menentukan size adalah total sales dan jumlah karyawan.

Dari pengujian hipotesis 1-4, diperoleh hasil sebagai berikut:

Tabel 3 Hasil Pengujian Hipotesis 1-4

\begin{tabular}{|c|c|c|}
\hline H1 & $\begin{array}{l}\text { Orientasi kepemimpinan berpengaruh positif terhadap kinerja operasional } \\
\text { perusahaan. }\end{array}$ & $\begin{array}{c}\text { Tidak } \\
\text { Signifikan }\end{array}$ \\
\hline H2 & $\begin{array}{l}\text { Inovasi proses berpengaruh positif terhadap kinerja operasional } \\
\text { perusahaan. }\end{array}$ & Signifikan \\
\hline H3 & $\begin{array}{l}\text { Inovasi produk berpengaruh positif terhadap kinerja operasional } \\
\text { perusahaan. }\end{array}$ & Signifikan \\
\hline H4 & $\begin{array}{l}\text { Implementasi inovasi berpengaruh positif terhadap kinerja operasional } \\
\text { perusahaan. }\end{array}$ & Signifikan \\
\hline
\end{tabular}

Hasil pengujian model penelitian ini yang terdiri dari tiga hipotesis yang terdukung dan satu hipotesis yang tidak terdukung, dan size sebagai variabel kontrol juga tidak ikut mempengaruhi kinerja operasional perusahaan, dapat dilihat dalam Gambar 2.

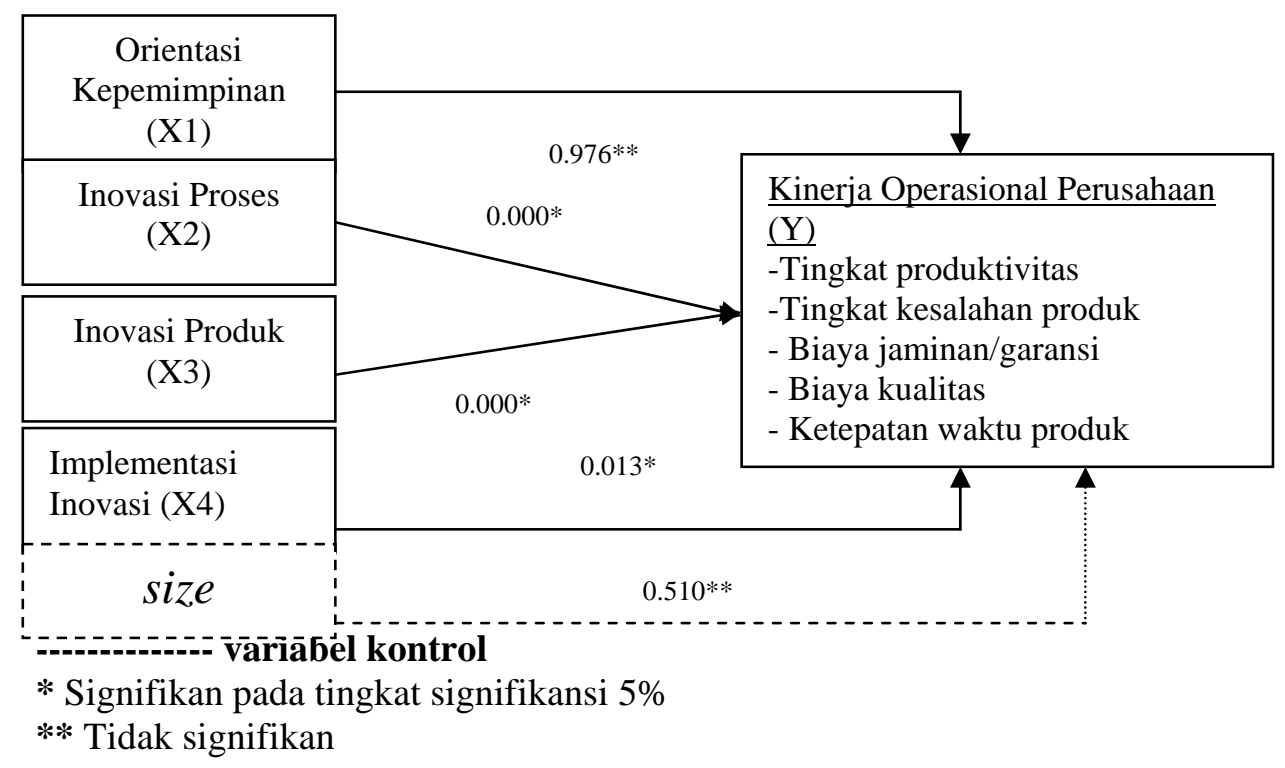

Gambar 2 Hasil Pengujian Analisis Regresi 


\section{SIMPULAN}

Penelitian ini merupakan replikasi dari peneltian Zahra dan Das (1993), yang meneliti pengaruh dimensi-dimensi strategi inovasi terhadap kinerja keuangan perusahaan manufaktur. Modifikasi yang dilakukan dalam penelitian ini adalah penambahan variabel implementasi inovasi sebagai salah satu dimensi strategi inovasi (Read, 2000), dan penggunaan kinerja operasional untuk mengukur kinerja perusahaan. Penggunaan kinerja operasional sebagai ukuran kinerja perusahaan didasarkan pada pendapat Kaplan dan Norton (1992) yang mengatakan bahwa ukuran keuangan dapat mengaburkan tanda-tanda yang berkaitan dengan peningkatan kinerja dan aktivitas-aktivitas inovasi. Indikator kinerja operasional mengacu pada penelitian yang dilakukan oleh Terziovski dan Samson (1999). Selanjutnya, memasukkan size sebagai variabel kontrol. Size mengacu dari penelitian Kemp, et al (2003) yang mengatakan bahwa size yang diukur dengan jumlah karyawan yang dimiliki oleh masing-masing perusahaan berpengaruh terhadap kinerja perusahaan. Pengujian dilakukan dengan menggunakan multiple regression. Hasil pengujian menunjukkan bahwa dari 4 hipotesis yang diajukan, hanya 3 hipotesis yang terdukung. Ketiga hipotesis tersebut adalah inovasi proses, inovasi produk, dan implementasi inovasi berpengaruh positif dan signifikan terhadap kinerja operasional perusahaan. Sedangkan orientasi kepemimpinan tidak memiliki pengaruh yang signifikan terhadap kinerja operasional perusahaan, berbeda dengan hasil penelitian Zahra dan Das (1993). Perbedaan hasil penelitian ini dengan hasil penelitian yang dilakukan oleh Zahra dan Das (1993) adalah tidak terdukungnya hipotesis yang mengatakan ada pengaruh orientasi kepemimpinan terhadap kinerja operasional perusahaan. Perbedaan ini disebabkan oleh variabel orientasi kepemimpinan dalam penelitian ini bersifat market oriented. Akan lebih tepat bila variabel orientasi kepemimpinan yang digunakan adalah orientasi kepemimpinan teknologi. Porter (1990) mengemukakan bahwa kepemimpinan teknologi merupakan upaya perusahaan untuk menjadi yang pertama dalam memperkenalkan perubahan teknologi yang mendukung strategi generic perusahaan. Selanjutnya size, juga tidak berengaruh terhadap kinerja operasional perusahaan. Berbeda dengan hasil penelitian Kemp, et al (2003).

Hasil penelitian ilmiah senantiasa harus dikembangkan secara mendalam dan berkesinambungan. Penelitian lanjutan perlu dilakukan karena penelitian ini mempunyai beberapa keterbatasan, yaitu (1) Penelitian ini hanya menguji pengaruh dimensi-dimensi strategi inovasi terhadap kinerja operasional perusahaan, tanpa melihat sudah berapa lama perusahaan menerapkan strategi inovasinya. Untuk penelitian selanjutnya, disarankan agar memasukkan variabel antara seperti kurun waktu perusahaan dalam menerapkan inovasi; (2) Penelitian ini hanya mengambil sampel pada perusahaan manufaktur yang ada di Sulawesi sehingga tidak dapat digeneralisasikan pada perusahaan selain perusahaan manufaktur, disarankan agar penelitian selanjutnya perusahaan jasa juga dilibatkan sebagai sampel penelitian sehingga diharapkan akan lebih menyempurnakan penelitian ini; (3) Penggunaan kriteria penggolongan ukuran perusahaan (size) hanya berdasarkan satu kriteria yaitu jumlah tenaga kerja yang dimiliki oleh masing-masing perusahaan yang berdasarkn pada Standar Biro Pusat Statistik (BPS), kriteria tersebut masih belum bisa dianggap menggambarkan keadaan perusahaan sesungguhnya. Penelitian selanjutnya sebaiknya tidak hanya menggunakan jumlah karyawan sebagai proksi dari size sesuai BPS, tetapi juga menggunakan total sales. Penelitian selanjutnya didukung oleh temuan dan saran dari penelitian Zhou dan Stan (1998), untuk proksi dari size sebaiknya menggunakan total sales dan jumlah karyawan; (4) Data penelitian yang berasal dari persepsi responden yang disampaikan secara tertulis dengan bentuk instrumen kuesioner, mungkin mempengaruhi validitas hasil. Persepsi responden belum tentu mencerminkan keadaan yang sebenarnya dan akan bebeda jika data diperoleh dengan wawancara. 


\section{DAFTAR ISI}

Anonym. (1985). Competitive advantage-creating and sustaining superior performance. The Free Press, 145-156.

Anonym. (1990). Competitive advantage-creating and sustaining superior performance. The Free Press, 145-156.

Anonym. (1990). A dynamic perspective on the impact of process innovation upon competitive strategies. Strategie Management Journal, 11, 25-41.

Anonym. (1993). Operation management: Decision making in the operation function, $4^{\text {th }}$ ed., McGraw Hill Inc.

Avionitis, G.J dan N.Tzokas. 1994. Assessing the Innovativeness of Organizations and its antecedents: Project Innovative. European Journal of Marketing, 28, (11), pp.5-28.

Baldwin, J. R. 1995. Innovation: The Key To Success In Small Firm, Working Paper Series, MicroEconomic Studies and Analysis Devision, Statistics Canada and Canadian Institute for Advanced Research Economic. Project Growth, No. 76.

Barton, L.D. (1991). The role of process innovation and adaptation in attaining strategic technological management, 6(3), 303-320.

Biro Pusat Statistik (BPS). 2003.Statistik Industri Perusahaan Manufaktur Skala Menengah dan Besar, Jakarta, Indonesia.

Bustamante, P. (1999). Knowledge management in agile innovation organizations. Journal of Knowledge Management, 3(1), 6-17.

Cooper, J.R. 1998. A Multidimensional Approach to The Adoption of Innovation. Management Decision, 36, 8: 493-502.

Cottam, A.J. Ensor, and C. Band. 2001. A Benchmark Study of Strategic Commitment to Innovation, European Journal of Innovation Management, 4 (2), pp. 88-94.

Cumming, B.S. (1998). Innovation overview and cuture challenges. European Journal of Innovation Management, 1(1), 21-29.

Damanpour, F. (1991). Organizational innovation: A meta-analysis of effects of determinants and moderators. Academy of Management Journal, 34(3), 555-590.

Ettlie, J.E., and Reza, E.M. (1992). Organizational integration and process innovation. Academy of Management Journal, 53(4), 795-827.

Frambach, R.T., and Schillewaert, N. (2002). Organizational innovation adoption: A multilevel framwork o determinants and opportunities for future research. Journal of Business Research, 55(2), 163-176.

Ghozali, I. (2005). Aplikasi analisis multivariate dengan program SPSS, edisi ketiga, Universitas Diponegoro Press, 56-69. 
Gibson, L.J., Ivancevich, M. J., and Donelly, H.J.Jr. (1995). Organizations, $8^{\text {th }}$ ed., Richard D. Irwin, Inc.

Johne, A. (1999). Successful market innovation. European Journal of Innovation Management, 2(1), 6-11.

Kaplan, R.S., and Norton, D.P. (1992). The balance scorecard measure that drive performance. Harvard Business Review, 3, 71-79.

Kemp, R.G.M, Folkeringa, M., De Jong, J.P.J., and Wubben, E.F.M. (2003). Innovation and firm performance: Differences between small and medium-sized firms. Scientific Analysis of Enterpreneurship and SMEs.

Khan, A.M., and Manopicketwattana, V. (1989). Innovative and noninnovative small firm: types and characteristic. Management Science, 4, 597-606.

Klein, K.J., and Sorra, J.S. (1996). The challenge of innovation implementation. Academy of Management Review, 1055-1077.

Krubasik, E.G. (1988). Customize your product development. Harvard Business Review, 66(6), 46-52.

Leong, G.K., Synder, D.L., and Waed, P.T. (1990). Reseach in the process and conted of manufacturing strategy. Omega, 28, 109-122.

Lukas, B.A., and Ferrel, O.C. (2000). The effect of market orientation product innovation. Journal of Academy of Marketing Science, 28(2), 239-247.

Mavondo, F., and Farrel, M. (2003). Cultural orientation: Its relationship with market orientation, innovation, and organizations performance. Management Decision, 41(3), 241-249.

Melum, M. (2002). Developing high performance leaders. Quality Management in Health Care, 11, 55-68.

Mintzberg, H., and Quinn, J.B. (1991). The strategy process, contexts, and class, Practice Hall International Inc.

Morse, S. (1998). Successful product management. Marketing in Action Series, edisi Indonesia, Jakarta: PT Gramedia.

Noori, H., and Radford, R. (1995). Production and operation management: Total quality and responsiveness, USA: Mc Graw-Hill, Ine.

Porter, M.E. (1980). Competitive strategy - technique for analyzing industries and competitive. The Free Press, 145-156.

Read, A. (2000). Determinant of sucessful organizational innovation: A review of current research. Journal of Management Practice, 3(1), 95-119.

Schroeder, R.G., Anderson, J.C., and Cleveland, G. (1986). The content of manufacturing strategy. Journal of Operation Management, 6(4), 367-389. 
Sharma, B., and Fisher, T. (1997). Functional strategies and competitiveness: An empirical analysis using data from Australian manufacturing. Bencmarking for Quality Management and Technology, 4, 286-294.

Sharma, U. (2000). Managerial interpretations and organizational context as predictors of corporate choice of enviromental strategy. Academy of Management Journal, 43(4), 681-697.

Terziovski, M., Samson D., and Douglas, Dow. (1997). The business value of quality management system certification evidence from Australia and New Zeland. Journal Operation Management, 15, 1-18.

Terziovski, M., and Samson, D. (1999). The link between total quality management, 16(3), 1-18.

Utterback, J.M. (1994). Mastering the dynamics of innovation: How companies can seize opportunities in the faced of technological change Boston. Harvard Business School Press.

Zahra, S.A., and Das, S.R. (1993). Innovation strategy and inancial performance in manufacturing companies: An empirical study. Production and Operation Management, 2(1), 15-37.

Zhou, S., and Stan, S. (1998). The determinants of export performance: A review of the empirical literature between 1987-1997. International Marketing Review, 15(5), 333-356. 